\title{
Does Women Well-being Matter for Demand and Development of Children?
}

\author{
Muhammad Qasim ${ }^{1}$ (D) , Muhammad Abrar ul Haq² (D) , Tariq Hussain ${ }^{3}$ (D) , Charagh Roshan ${ }^{4}$
}

\begin{abstract}
Women well-being has number of socioeconomic and developmental implications. Early child development is directly linked with well-being of mothers and educated women demand lower children. However, the existing literature hardly focused this area, therefore, the current study has investigated the impact of women wellbeing on fertility and early child development. For this purpose, this study constructed women well-being index to measure the well-being of the women by using four dimensions, economic well-being of women, social well-being of women, political awareness of women and satisfaction of women in different aspects of life. Moreover, early child development index has considered as proxy for child development which covers four dimensions of early child development, literacy-numeracy of children, physical growth of children, learning of children and socio-emotional development of children. In this connection, the data was collected from thirty-six districts across the Punjab province, Pakistan. By applying descriptive and regression analysis, the study found that women well-being has positive association with all domains of early child development. However, women well-being and its dimensions have negative relationship with fertility. Therefore, improvement in well-being of women may a suitable strategy especially for developing economies to enhance early child development and to reduce demand of children.
\end{abstract}

\section{Keywords}

Women Well-Being • Early Child Development • Demand of Children

\footnotetext{
1 Corresponding author: Muhammad Qasim (Asst. Prof.), The University of Lahore, Department of Economics, Pakistan. Email: muhammad.qasim@econ.uol.edu.pk

2 Muhammad Abrar ul Haq (Asst. Prof.), AMA International University, Bahrain. Email: abrarchudhary@hotmail.com

3 Tariq Hussain (Asst. Prof.), The University of Lahore, Department of Economics, Pakistan. Email: tariq.hussain@econ.uol.edu.pk

4 Charagh Roshan (M.Phil), The University of Lahore, Pakistan. Email: charagh80@gmail.com

To cite this article: Qasim, M., ul Haq, M. A., Hussain, T., \& Roshan, C. (2018). Does women well-being matter for demand and development of children? Ekoist: Journal of Econometrics and Statistics, 14(29), 169-197. https://doi.org/10.26650/ekoist.2018.14.29.0012
} 


\section{Introduction}

Wellbeing of women has become an important strategy not only to improve living standard and welfare of a household as well as of the economy. As a Sustainable Development Goal (SDG), women wellbeing has number of socioeconomic implications and consequences. Women have significant contribution in economic growth and development of a society (Da Rocha \& Fuster, 2006; Fernandez et al, 2014; Ozerkek, 2013; Trommlerova et al., 2015; WHO, 2005). Moreover, improving the status and ability of women is not only useful for economic development, it is also crucial for early child development and human development (Duflo, 2012). Therefore, it is believed that special focus is needed to improving women life and that wellbeing of women have spillover effects.

Women wellbeing is critical to ensuring healthy children, prosperous families, healthy communities and developed nations. Lower women wellbeing and depressed women have adverse consequences for children (Salt et al., 1988; Patel \& Prince, 2006; Falceto et al., 2004; Galler et al., 2004; Minkovitz et al., 2005; Galler et al., 2006; Black et al., 2007; Grote et al., 2010; Surkan et al., 2011; Bohren et al., 2015). Furthermore, the children who grow up in families with less wellbeing have lower early child development (Hair, Hanson, Wolfe, \& Pollak, 2015). Early child development has direct association with economic, social and emotional wellbeing of the families. Early development of children is directly associated with maternal health (Benner \& Kim, 2010) and mother's education and health have positive relationship with child survival. While there is need to understand that female education has no pre-assumed more effect on child survival as compared to male education. According to Ashraf, Abrar-ul-Haq and Ashraf, (2017) educated women are more careful regarding their children's welfare as well as they also demanded fewer children than uneducated women. Similarly, the households where income is in the hands of women have less malnutrition and more children's welfare as compared to the households where income is in the hands of men (Abrar ul Haq, Jali, \& Islam, 2016). Likewise, malnutrition in early child development stage limits mental and physical development, educational achievement and economic productivity later in life, powering intergenerational cycles of poverty and undernutrition and lower well-being of women has been identified as one of the key responsible factors of undernutrition (Hoddinott et al., 2013).

Some studies indicate that emotional wellbeing of women enhances physical health of children and it has been the main concern of different researchers (Berghet al., 2008; Weinstock, 2008; DiPietro et al., 2008; O’Donnel et al., 2009; Glover, 2011; Lange \& Randler, 2011). Moreover, it is also evident that the emotional stresses of women reduce physical growth of children (Rondó et al., 2003). In this regard, the maternal stress, maternal education, mother's socioeconomic status, smoking, consumption of alcohol has been explored key determinants of physical health of 
children (Gennaro, 2005; Aliyu et al., 2010; Keegan et al., 2010; Wadhwa et al., 2001). Furthermore, the early child development is predicted by family wellbeing and parental quality (Roggman, Boyce, \& Innocenti, 2008; Rafferty, Griffin, \& Robokos, 2010; Newland et al., 2014). Similarly, the early child development suffers when their families are struggling (Newland, 2015).

Moreover, the Parents with low income and low education levels also tend to lower health outcomes, which further lead to lesser children health (Topal, Ozkul, \& Dagli, 2017; Case \& Paxson, 2002). Parents' health, education and economic support are crucial to enhancing early child development. This postulates that early child development may directly affected from women wellbeing, which is relating to economic, social, emotional and physical wellbeing of women as well as life satisfaction of women. It improves child quality, which is helpful to make quality citizen in future (Vandell, Belsky, Burchinal, Steinberg, \& Vandergrift, 2010). Early childhood development is defined as an orderly, predictable process along a continuous path, in which a child learns to handle more complicated levels of moving, thinking, speaking, feeling and relating to others. Furthermore, the physical growth, literacy and numeracy skills, socio-emotional development and readiness to learn are vital aspects of a child's overall development, which is a basis for overall human development (Shieh, Chou, \& Ersozlu, 2018)

On the other hand, gender inequality and less wellbeing of women are not only a primary cause of their poverty, but it also argued that it is the most important cause of rapid population growth (Cornwall, 2015). The societies where women are less educated, unhealthy and have little access to productive resources, little income, little decision-making power have large number of children (Brinda, Rajkumar, \& Enemark, 2015), Ashraf et al., 2017, Cain, 1984; Dyson \& Moore, 1983; \& Jacobson, 1992). In family planning, wellbeing and empowerment of women has attained central importance to reduce fertility (Ulbrich, Health, \& 2002; Petchesky \& Weiner, 1990; Germain \& Ordway, 1989). They argue that without education of women, health facilities, freely access to markets, independent decision making in household, political independence, religious independence the policy of direct family planning cannot be helpful to reduce fertility (Ulbrich, Health, \& 2002). The importance of gender-based empowerment and equality dynamics have been increased in demographic literature (Bick, 2016; Blanc, 2001; Mason \& Smith, 2000; McDonald, 2000; Sen \& Batliwala, 2000). Specifically, it has been suggested that economic, social, emotional and political well-being of women wellbeing are important factors as strategy to reduce fertility especially in developing economies of the world. However, it can be achieved by providing basic facilities of education and health to women as well as by providing self-esteem and dignity to women, as women wellbeing may a worthwhile strategy to enhance early child development and to reduce fertility of a society. Therefore, the key objective of the current study is to investigate the impact of women wellbeing on 
fertility as well as on early child development to find the answer of question 'Does women wellbeing matter for demand and development of children?'

\section{Literature Review}

Women and child development have been the great concern of the researchers. Different researchers studied various implications of women and human well-being (Chandra et al., 2009; Blanchflower \& Oswald, 2008; D’Acci, 2011; Davidson et al., 2011; Trzcinski \& Holst, 2012; Doepke \& Tertilt, 2014; Stillman et al., 2015;). Moreover, in existing literature most of the researchers studied the contribution of women in economic growth and economic development (Such as, Sharma, 2008; Lincove, 2008; Fatima \& Sultana, 2009; Klasen \& Lamanna, 2009; De la Croix \& Donckt, 2010; Fatima, 2011; Chaudhary et al., 2012; Rodenberg \& Pahle, 2012; Duflo, 2012; Rees \& Riezman, 2012; Tsani et al., 2012; Ekesionye \& Okolo, 2012; Mujahid \& Zafar, 2012; Mukherjee \& Mukhopadhyay, 2013; Fernandez, 2014; Doepke \& Tertlt, 2014; Xu, 2015; Khayria \& Feki, 2015). However, on the other hand, few researchers have observed the impact of mothers' wellbeing on wellbeing of their children at micro level. They have investigated the impact of various aspects of women wellbeing on early child welfare by using microanalysis. Most of these studies are about parenting, family wellbeing and children wellbeing.

Early child development is directly and indirectly based on family wellbeing especially well-being of mothers. Numerous studies have found that early child development is predicted by parenting wellbeing and quality (McKeown, Pratschke, \& Haase, 2003; Newland et al., 2014; Rafferty, Griffin, \& Robokos, 2010; Roggman, Boyce \& Innocenti, 2008; Ummanel, Şahin Kıralp, \& Yiğit, 2017) and also early child development suffers due to lower well-being of parents (Newland, 2014). Frequent literature identified important parenting and family factors to determine child wellbeing (Belsky \& Pluess, 2009; Pluess \& Belsky, 2013). The parents who have poor wellbeing, it affects the children development as well as to entire system of family (Newland, Coyl \& Freeman, 2008; MacKenzie, Nicklas, Brooks-Gunn, \& Waldfogel, 2011). Moreover, parental physical and emotional wellbeing is equally important for whole family and children (Case \& Paxson, 2002). Similarly, parents' physical health and behaviour are directly related to family functioning which further impact child outcomes (Giallo et al., 2013; Hogg, Ritchie, de Kok, Wood, \& Huby, 2013; Pancer et al., 2013; Newland, 2014). According to Gase \& Passon (2002), parents are a primary source of inspiration and guideline for their children to improve health, learning, physical growth, social and emotional development. Therefore, the quality of parenting is important for quality development of the children (Newland et al., 2013, 2014). As high quality of parenting is developmentally suitable, steadily meets the child's wants and is used as those needs change in order to adoptive children's wellbeing (Cabrera et al., 2008; Roggman et al., 2008; Newland et al., 2008, 2013). 
Moreover, there are some studies which have concluded direct connections from family wellbeing to child well-being outcomes (Newland et al., 2013). Likewise, the relationship among parenting, maternal health and outcomes of child wellbeing like physical growth, learning of children, social and emotional development of children is being studied consistently from last two decades. In those works, the wellbeing of the women is linked with children qualities such as their health, education and improvement in physical growth (Coyl et al., 2002; Farver et al., 2005). In this regard, many dimensions of family well-being are important for early child wellbeing like child health outcomes, including birth weight, sudden infant death syndrome, childhood injuries and health-risk behaviours (Case \& Paxson, 2002). Many studies have found that wellbeing of children is indirectly connected with family well-being through parents' child interaction (Coyl et al., 2002; McLoyd, 1998; Freeman et al., 2010; Rafferty et al., 2010; Ziegert, 2011). Furthermore, maternal employment has also significant association with child nutrition, child education, learning and improvement in early skills of children (Ruhm, 2004; Love et al., 2003; Vogl, 2015). Thus, the review of above literature shows that wellbeing of family and parents are significantly useful to improve early outcomes of children at household level. Women wellbeing may have significant association with early child development at macro as well as across the regions of a country. Moreover, the empirical literature regarding the relationship of women wellbeing with different aspects of early child development among the regions of a country is not found commonly. Therefore, the present study has investigated the impact of different dimensions of women wellbeing on various aspects of early child development across the regions of Punjab, Pakistan. Thus, this study contributes significantly in existing literature related to wellbeing of women and early child development.

While women wellbeing is not only important for early child development, its demographic implications also have been studied by different social scientists as well. There is an inverse association between women wellbeing and fertility (Hindin, 2000; Peddie, Menon, 2013; Teijlingen, \& Bhattacharya, 2004). Moreover, there is enough evidence that empowering women through education, health, political awareness and decision-making power reduces their fertility (Kull, 2002; Kritz, 2000; Moursund \& Kravdal, 2003; Kohler, Behrman \& Skytthe, 2005; Woldemicael, 2009; Upadhyay \& Karasek, 2012). Educated women have small family size as compared to uneducated women (El-Zeini, 2008; Monte \& Illis, 2009; Woldemicael, 2009; Khan et al., 2009; Upadhyay \& Karasek, 2012). Various studies have shown the importance of socioeconomic factors including women status to reduce their fertility (Hirschman, 2001; Rindfuss, Bumpass \& John, 1980).

Furthermore, employment opportunities of women have significant contribution to decline their fertility (Wanamaker, 2012). In this connection, the empirical literature shows that fertility is negatively associated with female education and labor force 
participation (Mason, 1987). It is also observed that female educational attainment and labor force participation has contributed to fertility decline in developing countries (Jejeebhoy, 1995; Lam \& Duryea, 1999). Moreover, Rocha \& Fuster (2006) studied the relationship between female employment and fertility in organization economic co-operation and development (O.E.C.D) countries. By applying household's data and General Least Square (GLS) they found positive relationship between female employment and fertility (Fuchs, 2017; Rocha \& Fuster, 2006). Furthermore, Sharma (2008) discussed that women education is the key factor to change the social and economic status of a society. Thus, universal primary education of both gender is important for reducing poverty, achieving high growth rate and socio-economic development and higher cost of children reduces the fertility which may cause to increase their per capita savings (Becker, Murphy \& Tamura 2007; Fuchs, 2017). Theoretically, fertility affect growth positively as well as negatively. High fertility reduces economic growth by increasing dependency ratio, reducing women labour force participation (Bloom \& Williamson, 1998; Klasen, 2000). However, improvement in the status of women through education and labour force participation reduces fertility and enhances economic development (Coleman, 2004). Moreover, female autonomy also decreases fertility rate and increase the expenditure on child well-being (Dyson \& Moore, 1983; Abadian, 1996; Gage, 1995; Jejeebhoy, 1995).

\section{Date and Methodology}

Data of all variables of women wellbeing such as proportion of women who have job, percentage of women who have personal income, percentage of women have pre-natal and post-natal health facility, proportion of literate women, percentage of women who are used computer and internet, proportion of women having mass media exposure and percentage of women who are satisfied from life, health, living environment, friends and relatives, as well as constructed data related to early child development index (ECDI) and its four dimensions, total fertility and other control variables vitamin, under-five mortality rate, unemployment rate, per capita income of all districts, material for playing of children, percentage of children having books, immunization rate and gender parity index for secondary education (GPS) has been collected from Multiple Indicator Cluster Survey, (2014). Multiple Indicator Cluster Survey (MICS, 2014) was conducted by Punjab Bureau of Statistics (PBS) with the collaboration of United Nations International Children's Emergency Fund (UNICEF). MICS (2014) collected data using questioners related to women, children and other characteristics of household at the regional stage, 9-divisions, 36-districts, and urban and rural areas of province Punjab, Pakistan. The total sample size was 41,000 households, located in 2050 sample clusters. More than half of the population of Pakistan resides in Punjab. This survey covers all districts of Punjab with appropriate sample from each district. MICS has calculated separate information about child development and women wellbeing through distinct questioners. 
Furthermore, in the light of above raised question, the following econometric models have been estimated. First five equations are related to the association of women wellbeing with early child development and its dimensions. Other five equations are explained the connections of women wellbeing and its dimensions with demand for children.

$$
\begin{aligned}
& E C D I_{i}=\mathrm{a}+\mathrm{b}_{1} V A_{i}+\mathrm{b}_{2} W W I_{i}+\mathrm{b}_{3} L M P_{i}+\mathrm{b}_{4} U E R_{i}+\mathrm{e}_{i} \\
& L N C_{i}=\mathrm{a}+\mathrm{b}_{1} W W I_{i}+\mathrm{b}_{2} L M P_{i}+\mathrm{b}_{3} U E R_{i}+\mathrm{b}_{4} L M B_{i}+e_{i} \\
& L O C_{i}=\mathrm{a}+\mathrm{b}_{1} W W I_{i}+\mathrm{b}_{2} L M P_{i}+\mathrm{b}_{3} U E R_{i}+\mathrm{b}_{4} L M B_{i}+\mathrm{b}_{5} V A_{i}+e_{i} \\
& P G C_{i}=\mathrm{a}+\mathrm{b}_{1} W W I_{i}+\mathrm{b}_{2} L M P_{i}+\mathrm{b}_{3} U E R_{i}+\mathrm{b}_{4} L M B_{i}+e_{i} \\
& S E D C_{i}=\mathrm{a}+\mathrm{b}_{1} W W I_{i}+\mathrm{b}_{2} L M P_{i}+\mathrm{b}_{3} U E R_{i}+\mathrm{b}_{4} L M B_{i}+e_{i} \\
& T F_{i}=\mathrm{a}+\mathrm{b}_{1} W W I_{i}+\mathrm{b}_{2} P C I_{i}+\mathrm{b}_{3} G P S_{i}+u_{i} \\
& T F_{i}=\mathrm{a}+\mathrm{b}_{1} E W W_{i}+\mathrm{b}_{2} P C I_{i}+\mathrm{b}_{3} G P S_{i}+u_{i} \\
& T F_{i}=\mathrm{a}+\mathrm{b}_{1} S W W_{i}+\mathrm{b}_{2} P C I_{i}+\mathrm{b}_{3} G P S_{i}+u_{i} \\
& T F_{i}=\mathrm{a}+\mathrm{b}_{1} P A W_{i}+\mathrm{b}_{2} P C I_{i}+\mathrm{b}_{3} G P S_{i}+u_{i} \\
& T F_{i}=\mathrm{a}+\mathrm{b}_{1} S O W_{i}+\mathrm{b}_{2} P C I_{i}+\mathrm{b}_{3} G P S_{i}+u_{i}
\end{aligned}
$$

Where,

$\mathrm{ECDI}=$ Early Child Development Index

LNC $=$ Literacy and Numeracy of Children

LOC $=$ Learning of Children

PGC $=$ Physical Growth of Children

$\mathrm{SEDC}=$ Socio-emotional Development of Children

$\mathrm{WWI}=$ Women Wellbeing Index

$\mathrm{VA}=$ Vitamin A

LMP $=$ Material for Playing of Children

UER $=$ Unemployment Rate

LMB $=$ Percentage of Children Having Books

$\mathrm{TF}=$ Total Fertility Rate

EWW = Economic Wellbeing of Women

SWW $=$ Social Wellbeing of Women

PAW $=$ Political Awareness of Women

PCI $=$ Per Capita Income

GPS $=$ Gender Parity Index

SOW $=$ Life Satisfaction of Women

$\mathrm{e}, \mathrm{u}=$ Error Terms

(i) = Subscript used for Cross Section (District) 
In this connection, the demand of children has measured by total fertility rate of specific district. To quantify women wellbeing, this study has calculated a composite index by using four dimensions, economic well-being of women, social well-being of women, and political awareness of women and satisfaction of women in various aspects of life. Moreover, the early child development index (ECDI) has considered as proxy for early child development which had calculated by Punjab Bureau of Statistics with the collaboration of United Nations International Children's Emergency Fund (UNICEF) in Multiple Indicator Cluster Survey MICS (2014). ECDI is a composite measure of four dimensions, literacy and numeracy of children, physical growth of children, learning of children and socio-emotional development of children. Thirtysix districts of Punjab province are considered as study area. The measurement and description of variables are given below;

\section{a) Women Wellbeing Index (WWI)}

Women Wellbeing Index has calculated by using four dimensions, economic wellbeing of women, social wellbeing of women, satisfaction of women in different aspects of life as well as political awareness of women. Economic wellbeing of women has estimated by considering the percentage of women in a district (region) who have jab and income. Social wellbeing of women has quantified by using three dimensions education of women, health of women and women efficacy in information technology. Education of women is measured by considering the percentage of literate women from age twenty-four to onward. Proportion of women who have pre-natal and postnatal health facility in specific region has used as proxy for women health. However, third variable women efficacy in information technology is measured by calculating the percentage of women who are frequently used computer and internet. Women exposure to mass media is used as proxy for political awareness. It is assumed that women who are used mass media like newspaper, television and radio have more political awareness as compared to others. Last dimension, satisfaction of women is measured by using five aspects of satisfaction, life satisfaction, satisfaction about health, satisfaction about living environment, satisfaction about friends and relatives. To construct composite index of women wellbeing with mentioned four dimensions Principal Component Analysis (PCA) method has applied.

\section{b) Early Child Development Index (ECDI)}

Early Child Development Index (ECDI) has used as proxy for child development. ECDI is a composite measure of four dimensions such as physical growth of children, socio-emotional development of children, literacy and numeracy of children and learning ability of children. ECDI indicates the proportion of children in a specific district who are on track of early child development in mentioned four dimensions. Literacy and numeracy of children means children are identified as 
being developmentally on track based on whether they can identify/name at least ten letters of the alphabet, whether they can read at least four simple, popular words and whether know the name and recognize the symbols of all numbers from 1 to 10 . If at least two of these are true, then the child is considered developmentally on track.

Similarly, physical growth of children means that, if the child can pick up a small object with two fingers, like a stick or a rock from the ground and/or the mother/ caretaker does not indicate that the child is sometimes too sick to play, then the child is regarded as being developmentally on track in the physical domain. Social and emotional development of children indicates that children are considered to be developmentally on track if two of the following are true: If the child gets along well with other children, if the child does not kick, bite or hit other children and if the child does not get distracted easily. Learning ability of children means that, if the child follows simple directions on how to do something correctly and/or when given something to do, is able to do it independently, then the child is considered to be developmentally on track in this domain. Punjab Bureau of Statistics PBS calculated ECDI in its report of MICS (2014 with four mentioned domains with the collaboration of UNICEF. This study used ECDI and its four dimensions as proxy for early child development.

\section{Data Analysis}

Various techniques have applied for empirical estimation of data. In this regard, both descriptive and inferential statistics have been applied. Women wellbeing index has been constructed by applying Principal Component Analysis (PCA) method. PCA is a multivariate statistical technique that can be used to reduce the number of variables in a dataset by converting them into a smaller number of components; each component being a linear weighted combination of the initial variables (Vyas \& Kumaranayka, 2006). The first component, which explains the largest part of the variation in the data, is chosen as the women wellbeing index. Moreover, to investigate the degree of relationship and correlation among various dimensions of women wellbeing, total fertility and different domains early child development scatter graphs, the Ordinary Least Square (OLS), different diagnostic tests like coefficient stability test (CUSUM and CUSUM SQUARE), serial correlation test, heteroscedasticity test, multicollinearity test and partial correlation coefficient have been applied.

\section{Empirical Findings}

Degree of relationship and correlation among different dimensions of women wellbeing, total fertility and various domains of early child development has estimated by applying descriptive statistics, regression analysis, diagnostic tests and correlation matrix. Main empirical findings are divided in three parts, first related 
to PCA results about women wellbeing index and its dimensional indices, second relevant to the degree of relationship and correlation among women wellbeing, fertility and early child development and third about diagnostic tests as discussed in following subsections.

\section{PCA Weights for Women Wellbeing}

PCA computes four eigenvalues, reports 1 average value about economic wellbeing of women, social wellbeing of women, political awareness of women and satisfaction of women in various aspects of life. Four components are extracted from four possible components. The values of 4 components are 2.0230, 1.1804, 0.7126 and 0.0839 respectively, which indicates that principal component 1 has higher value as compared to others. Proportions of 4 components are 0.5058, 0.2951, 0.1782 and 0.0210 respectively. Principal component (PC) 1 has higher proportion with value 2.0230 from 4. First two components have 0.8009 cumulative proportion. We have selected PC 1 in which economic wellbeing of women explains -0.0991 variation, 0.3159 by satisfaction of women, 0.6636 by political awareness and 0.6707 by social wellbeing of women.

\section{Social Wellbeing of Women}

Social wellbeing of women reports values $2.3588,0.4341$ and 0.2070 for 3 principal components respectively. PC 1 indicates higher value 2.3588 from 3 with 0.7863 proportion. Selected PC 1 assigns 0.5425 weight of variation by women health, 0.5971 by women efficacy in information technology and 0.5907 by women education.

\section{Satisfaction of Women in Various Aspects of Life}

Furthermore, the PCA reports eigenvalues of 5 components of satisfaction of women in five aspects, life satisfaction, and satisfaction about health, satisfaction about living environment, satisfaction about friends and relatives. PC 1 comprises 3.2183 value from 5 with higher proportion 0.6437 . Women satisfaction about living environment shows 0.5003 variation in PC $1,0.4275$ by women satisfaction about friends, 0.2968 by women satisfaction about health, 0.4817 by women satisfaction about life and 0.4966 by women satisfaction about other relatives.

\section{Political Awareness of Women}

Similarly, the eigenvalues of 3 components indicate higher value 2.3090 of PC 1 with higher proportion 0.7697 . PC 1 reports 0.5275 weight of women listening radio on the basis of variation. $\mathrm{O} .6205$ attains women reading newspaper and women watch television achieve 0.5802 weight. 


\section{Economic Wellbeing of Women}

Women have jobs attains 0.7071 contribution in PC 1 variation and same achieve by women have income. On the other hand, eigenvalue of PC 1 is 1.8554 from 2 with proportion of 0.9272 , PC 2 shows only 0.0728 proportion with 0.1456 eigenvalue which is very low as compared to PC 1 . PC 1 is adopted for economic wellbeing calculation. Degree of relationship and correlation of women wellbeing with early child development and fertility has reported in next section 4.2.

\section{Degree of Relationship and Correlation among Women Wellbeing, Fertility and Early Child Development}

Moreover, this study estimated the degree of relationship and correlation of women wellbeing with early child development as well as with its four domains, literacy and numeracy of children, physical growth and learning of children and socio-emotional development of children. Similarly, degree of association and correlation of women wellbeing and its four dimensions, economic well-being of women, social wellbeing of women, political awareness of women and satisfaction of women in different aspects of life with demand of children (total fertility) has been investigated and the main empirical findings are reported in following sub-section 4.2.1 and 4.2.2.

\section{Women Wellbeing and Early Child Development}

In this connection, the Figure 1, 2, 3, 4 and 5 respectively show that women wellbeing has positive association with early child development and its four domains, literacy and numeracy, learning of children, physical growth of children and socioemotional development of children. Figure 1 describes the relationship between women wellbeing and early child development. Women wellbeing has quantified

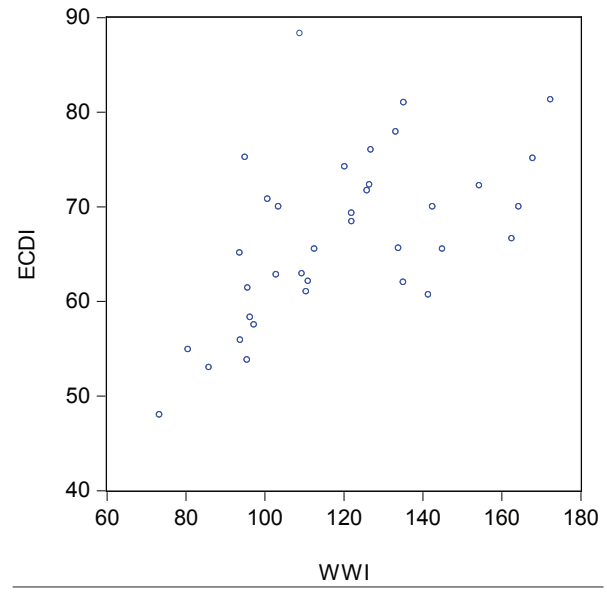

Figure 1. Association between Women Wellbeing Index (WWI) and Early Child Development Index (ECDI)

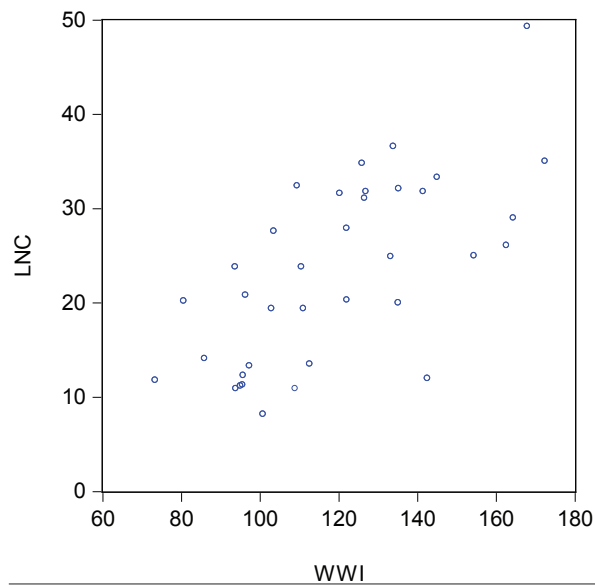

Figure 2. Association between Women Wellbeing Index (WWI) and Literacy and Numeracy of Children $(L N C)$ 


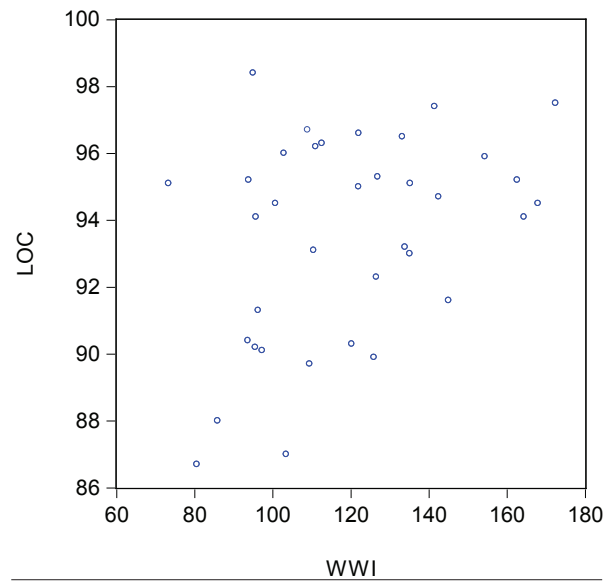

Figure 3. Association between Women Wellbeing Index (WWI) and Learning of Children (LOC)

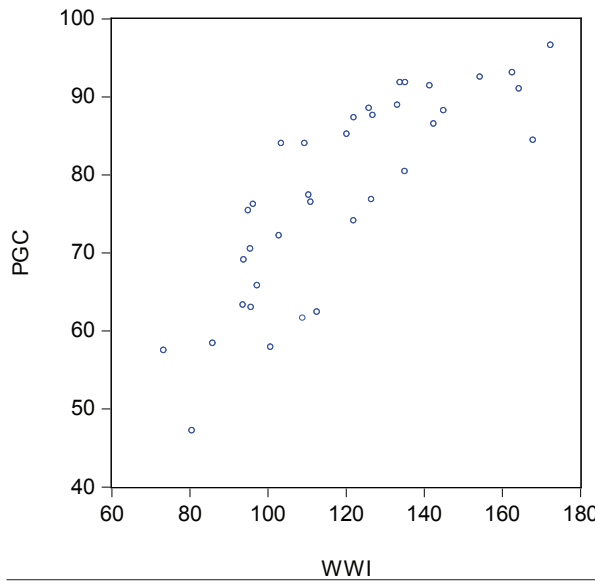

Figure 4. Association between Women Wellbeing Index (WWI) and Physical Growth of Children (PGC)

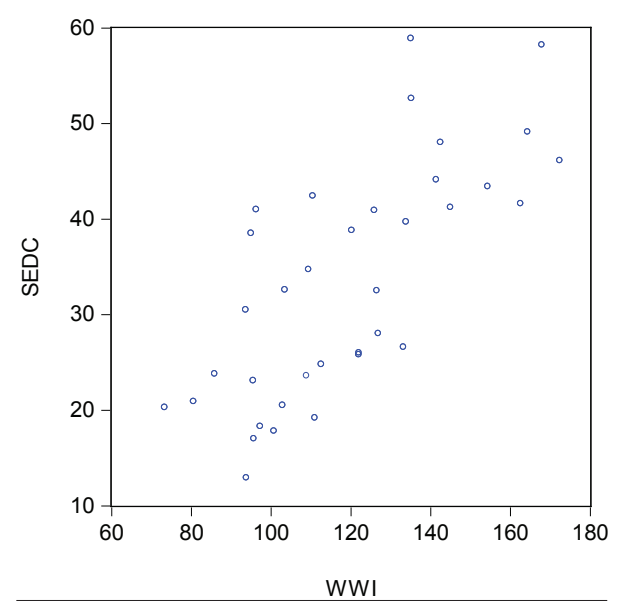

Figure 5. Association between Women Wellbeing Index (WWI) and Socio-emotional Development of Children (SEDC)

by calculating a composite index (women wellbeing index) with four dimensions, economic well-being of women, political awareness of women, social well-being of women and satisfaction of women in different aspects of life. Moreover, the Figure 2 depicts the relationship between women wellbeing and literacy-numeracy of children. Similarly, the Figure 3 shows the association of women wellbeing with learning of children. Likewise, the relationship of women wellbeing with physical growth of children has indicated in figure 4. Lastly, the Figure 5 postulates the connection between women wellbeing and socio-emotional development of children.

Furthermore, the regression estimates of five econometric equations in table-1 depict that women wellbeing index (WWI) has positive relationship with early child development index (ECDI) and its four domains, literacy and numeracy of children 
(LNC), learning of children (LOC), physical growth of children (PGC) and socioemotional development of children (SEDC). Women wellbeing has positive and significant association with early child development at 1 percent level of significance with probability value of 0.0018 . Coefficient value 0.1673 shows that 1 unit increase in women wellbeing improves 0.1673 unit early child development. From other control variables, vitamin (VA) has positive and significant relationship with early child development. However, material for playing (LMP) and unemployment rate (UER) are associated insignificantly with early child development. Explanatory power of first equation is 0.4293 with acceptable F-statistic 5.8320. Moreover, the results of second estimated econometric equation indicate that women wellbeing has positive and significant connection with literacy-numeracy of children with coefficient 0.1434 at 10 percent level of significance with probability value 0.0764 . Furthermore, from remaining three estimated econometric equations, it is also concluded that women wellbeing has positive and significant effect on learning of children, physical growth of children and socio-emotional development of children with coefficient 0.1345 , 0.3828 and 0.2731 respectively. Moreover, regarding significance level, women wellbeing and learning of children are significant at 5 percent, and with other two domains women wellbeing is significant at 1 percent level of significance. Other three econometric models have explanatory power $0.8423,0.7250$ and 0.6885 with acceptable F-statistics 32.0639, 20.4410 and 17.1365 respectively.

Table 1

Women Wellbeing and Early Child Development

\begin{tabular}{|c|c|c|c|c|c|c|c|c|}
\hline \multirow{2}{*}{$\begin{array}{l}\text { Dependent } \\
\text { Variable }\end{array}$} & \multicolumn{6}{|c|}{ Independent Variables } & \multirow[t]{2}{*}{ R2 } & \multirow[t]{2}{*}{ F-statistic } \\
\hline & WWI & LMP & VA & UER & LMB & C & & \\
\hline ECDI & $0.1673^{*}$ & 0.1148 & $0.1411 * * *$ & -0.7784 & - & 103.2197 & 0.4293 & 5.8320 \\
\hline LNC & $0.1434 * * *$ & 0.0426 & - & 0.0686 & $0.5178 * * *$ & -6.1736 & 0.4930 & 7.5360 \\
\hline LOC & $0.1345^{* *}$ & $0.2339 *$ & 0.0658 & -0.1357 & $1.0208^{*}$ & -2.2124 & 0.8423 & 32.0639 \\
\hline PGC & $0.3828 *$ & $0.2125^{* * *}$ & - & 0.6100 & 0.1482 & -37.0722 & 0.7250 & 20.4410 \\
\hline SEDC & $0.2731^{*}$ & $0.3402 * *$ & - & $-1.4332 * * *$ & 0.4238 & -10.4870 & 0.6885 & 17.1365 \\
\hline
\end{tabular}

Source: Author's Calculation

Note: $(*)(* *)(* * *)$ indicate significant at (1) (5) (10) \% level of significance

Correlation matrix in table-2 postulates that women wellbeing index (WWI) has higher degree correlation with early child development index (ECDI), literacynumeracy of children (LNC), learning of children (LOC), physical growth of children (PGC) and socio-emotional development of children (SEDC). However, with learning of children degree of correlation is lower as compared to other domains. Women wellbeing has $0.5596,0.6649,0.3789,0.8238$ and 0.7319 degree of coefficient with early child development and above mentioned four domains respectively. 
Table 2

Correlation Matrix of Women Wellbeing and Early Child Development

\begin{tabular}{lcccccc}
\hline & ECDI & LOC & LNC & PGC & SEDC & WWI \\
\hline ECDI & 1.000000 & 0.407163 & 0.378926 & 0.480403 & 0.371747 & 0.559685 \\
LRN & 0.407163 & 1.000000 & -0.080053 & 0.283323 & 0.079657 & 0.378924 \\
LTN & 0.378926 & -0.080053 & 1.000000 & 0.681912 & 0.624891 & 0.664966 \\
PHS & 0.480403 & 0.283323 & 0.681912 & 1.000000 & 0.694885 & 0.823897 \\
SFL & 0.371747 & 0.079657 & 0.624891 & 0.694885 & 1.000000 & 0.731988 \\
WWI & 0.559685 & 0.378924 & 0.664966 & 0.823897 & 0.731988 & 1.000000 \\
\hline
\end{tabular}

Source: Author's Calculation

\section{Women Wellbeing and Fertility}

In addition, the present study has also investigated the relationship of women wellbeing and its four dimensions, economic wellbeing, social wellbeing, political awareness of women and satisfaction of women in various aspects of life with fertility. By reporting five scatter Figure 6, 7, 8, 9 and 10, this study have found that women wellbeing and its mentioned four dimensions have negative relationship with fertility.

Regression estimates in Table-3 show that women wellbeing index (WWI) and its three dimensions, economic wellbeing of women (EWW), social wellbeing of women (SWW) and satisfaction of women (SOW) in different aspects of life have negative and significant connection with total fertility (TF) rate. However, political awareness of women (PAW) has negative and insignificant relationship with fertility. The coefficients of women wellbeing and its three dimensions, economic well-being of women, social well-being of women, and

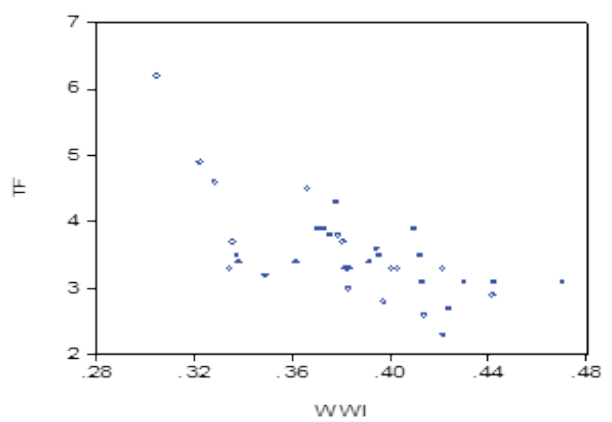

Figure 6. Relationship between Women Wellbeing Index (WWI) and Total Fertility (TF)

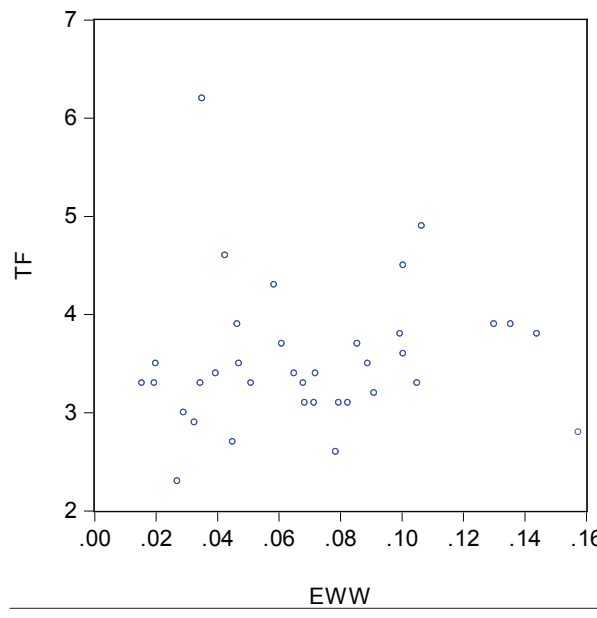

Figure 7. Relationship between Economic Wellbeing of Women (EWW) and Total Fertility (TF) 


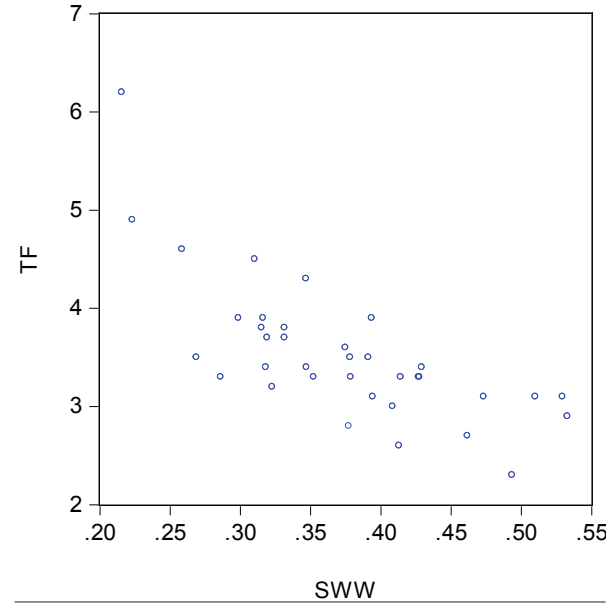

Figure 8. Relationship between Social Wellbeing of Women (SWW) and Total Fertility (TF)

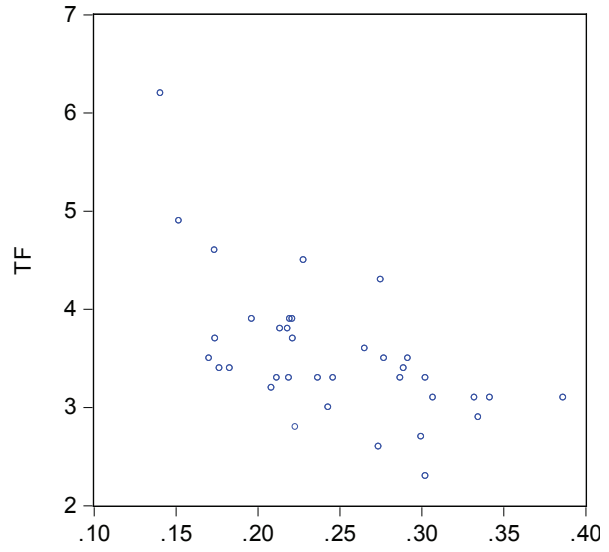

PAW

Figure 9. Relationship between Political Awareness of Women (PAW) and Total Fertility (TF)

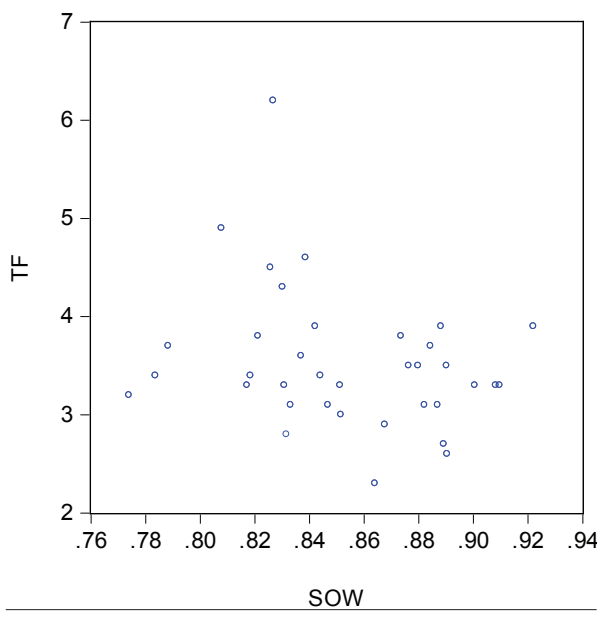

Figure 10. Relationship between Satisfaction of Women (SOW) in various aspects of life and Total Fertility (TF)

satisfaction of women in different aspects of life are $-9.2109,-0.0858,-5.6417$, and -4.9743 with respective probability $0.0259,0.0879,0.0025$ and 0.0603 . Political awareness of women negatively but insignificantly associated with fertility with probability value of 0.2402 . Explanatory power of mentioned five models are $0.4849,0.4511,0.5492,0.4609$, and 0.4229 respectively. From other control variables, per capita income (PCI) has been identified as useful factor to reduce fertility because it has negative connection with fertility in all econometric models. Gender parity index (GPS) has insignificant relationship with fertility. GPS is calculated MICS (2014) showing female to male ratio of secondary school enrollment. 
Table 3

Women Wellbeing and Fertility

\begin{tabular}{|c|c|c|c|c|c|c|c|c|c|c|}
\hline \multirow[t]{2}{*}{ DV } & \multicolumn{8}{|c|}{ Independent Variables } & \multirow[t]{2}{*}{$\mathbf{R} 2$} & \multirow[t]{2}{*}{ F-Statistic } \\
\hline & WWI & EWW & SWW & PAW & Sow & PCI & GPS & C & & \\
\hline $\mathrm{TF}$ & $-9.21 * *$ & - & - & - & - & $-7.94 * * *$ & 0.29 & 10.7492 & 0.49 & 10.05 \\
\hline $\mathrm{TF}$ & - & $-0.09 * * *$ & - & - & - & $-3.56^{*}$ & -0.19 & 3.1061 & 0.45 & 8.80 \\
\hline $\mathrm{TF}$ & - & - & $-5.64 *$ & - & - & -4.59 & 0.23 & 7.6855 & 0.55 & 12.99 \\
\hline $\mathrm{TF}$ & - & - & - & -3.30 & - & $-9.88 * * *$ & -0.15 & 9.3914 & 0.42 & 7.81 \\
\hline $\mathrm{TF}$ & - & - & - & - & $-4.97 * * *$ & $-15.00^{*}$ & -0.22 & 15.4294 & 0.46 & 9.12 \\
\hline
\end{tabular}

Source: Author's Calculation

Note: $(*)(* *)(* * *)$ indicate significant at (1) (5) (10) \% level of significance

Correlation matrix in Table-4 indicates negative correlation coefficient of women wellbeing index (WWI), economic well-being of women (EWW), social well-being of women (SWW) and political awareness of women (PAW) and satisfaction of women (SOW) in different aspects of life with total fertility (TF) rate. The values are $-0.6610,-0.0902,-0.7311,-0.5963$ and -0.2569 .

Table 4

Correlation Matrix of Women Wellbeing and Fertility

\begin{tabular}{lcccccccc}
\hline & EWW & TF & WWI & SOW & PAW & SWW & PCI & GPS \\
\hline EWW & 1.000000 & -0.090235 & -0.165990 & 0.241544 & -0.007561 & 0.038580 & -0.113604 & -0.249101 \\
TF & -0.090235 & 1.000000 & -0.661095 & -0.256923 & -0.596345 & -0.731102 & -0.621387 & -0.436606 \\
WWI & -0.165990 & -0.661095 & 1.000000 & 0.415637 & 0.924429 & 0.938275 & 0.716159 & 0.686766 \\
SOW & 0.241544 & -0.256923 & 0.415637 & 1.000000 & 0.221339 & 0.267706 & -0.020535 & 0.172379 \\
PAW & -0.007561 & -0.596345 & 0.924429 & 0.221339 & 1.000000 & 0.903074 & 0.762293 & 0.649025 \\
SWW & 0.038580 & -0.731102 & 0.938275 & 0.267706 & 0.903074 & 1.000000 & 0.748533 & 0.624569 \\
PCI & -0.113604 & -0.621387 & 0.716159 & -0.020535 & 0.762293 & 0.748533 & 1.000000 & 0.563477 \\
GPS & -0.249101 & -0.436606 & 0.686766 & 0.172379 & 0.649025 & 0.624569 & 0.563477 & 1.000000 \\
\hline
\end{tabular}

Source: Author's Calculation

\section{Diagnostic Tests}

Breush-Godfrey Serial Correlation LM test, ARCH Heteroscedasticity test and Variance of Inflation Factor (VIF) depict that there is no problem of serial correlation, heteroscedasticity and multicollinearity in all estimated econometric models. CUSUM and CUSUM SQUARE show that coefficients all econometric models are stable at 5 percent level of significance. 


\section{Women Wellbeing and Early Child Development Results of all Diagnostic Tests}

\begin{tabular}{|l|c|c|c|c|c|c|c|c|c|c|}
\hline Diagnostic Test & F-St & Prob. & F-St & Prob. & F-St & Prob. & F-St & Prob. & F-St & Prob. \\
\hline $\begin{array}{l}\text { ARCH } \\
\text { Heteroskedasticity Test }\end{array}$ & 0.41 & 0.22 & 0.99 & 0.42 & 0.96 & 0.45 & 0.00 & 0.95 & 0.01 & 0.91 \\
\hline $\begin{array}{l}\text { B-Godfrey Serial } \\
\text { Correlation LM Test }\end{array}$ & 0.05 & 0.94 & 1.81 & 0.18 & 0.37 & 0.68 & 1.10 & 0.34 & 2.11 & 0.13 \\
\hline $\begin{array}{l}\text { Mean Variance Inflation } \\
\text { Factor }\end{array}$ & \multicolumn{3}{|c|}{1.41} & \multicolumn{3}{|c|}{1.38} & \multicolumn{3}{|c|}{1.47} & \multicolumn{2}{|c|}{1.51} & \multicolumn{2}{|c|}{1.44} \\
\hline
\end{tabular}

Source: Author's Calculation

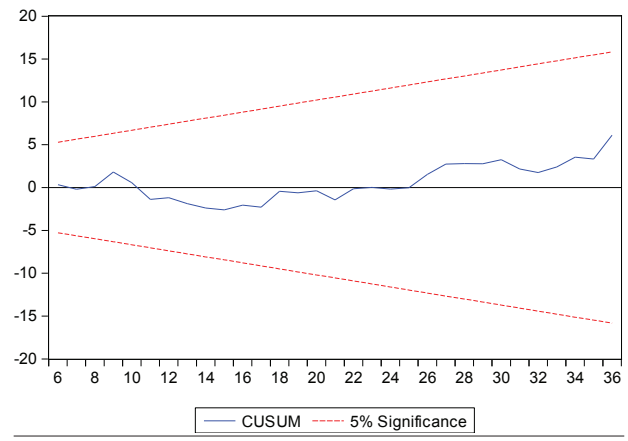

Figure 11. Women Wellbeing and Early Child Development (Coefficients Stability of First Regression Equation through CUSUM Estimates)

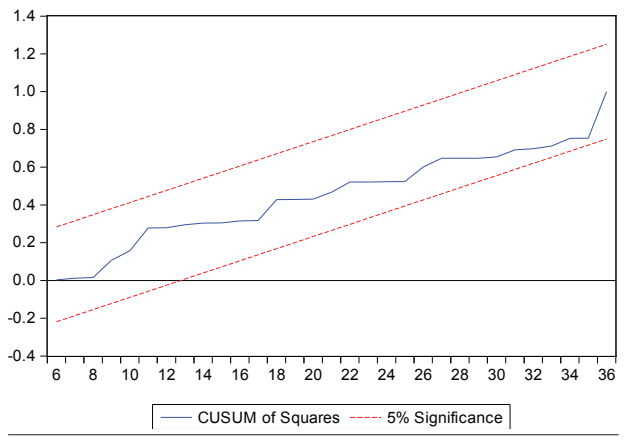

Figure 12. Women Wellbeing and Early Child Development (Coefficients Stability of First Regression Equation through CUSUM of Squares Estimates)

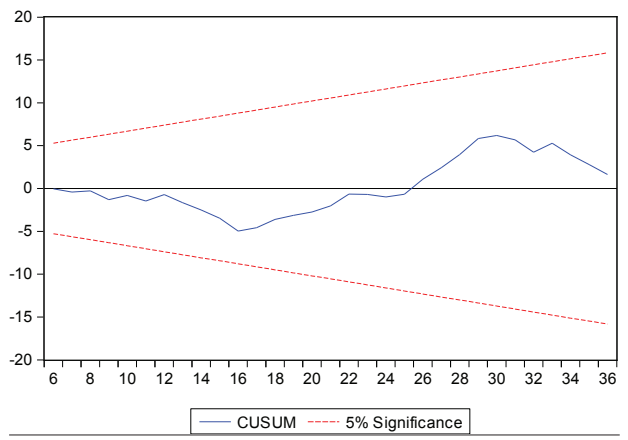

Figure 14. Women Wellbeing and Early Child Development (Coefficients Stability of Second Regression Equation through CUSUM of Squares Estimates) 


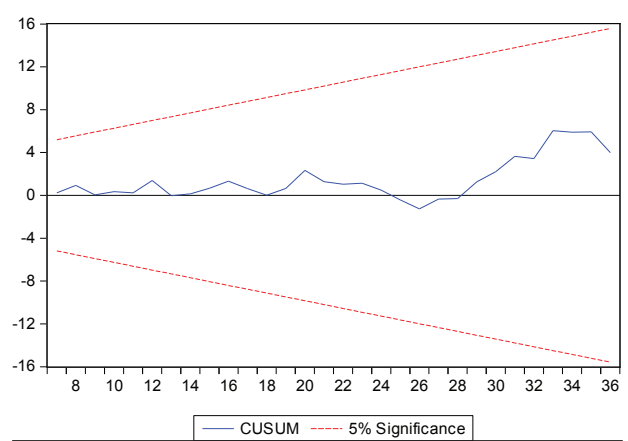

Figure 15. Women Wellbeing and Early Child Development (Coefficients Stability of Third Regression Equation through CUSUM Estimates)

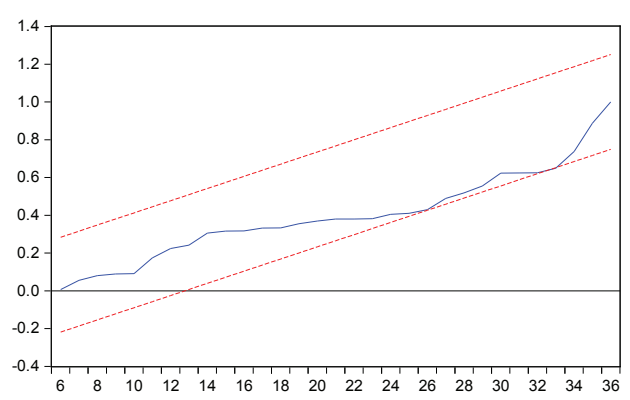

- CUSUM of Squares ----. $5 \%$ Significance

Figure 17. Women Wellbeing and Early Child Development (Coefficients Stability of Fourth Regression Equation through CUSUM Estimates)

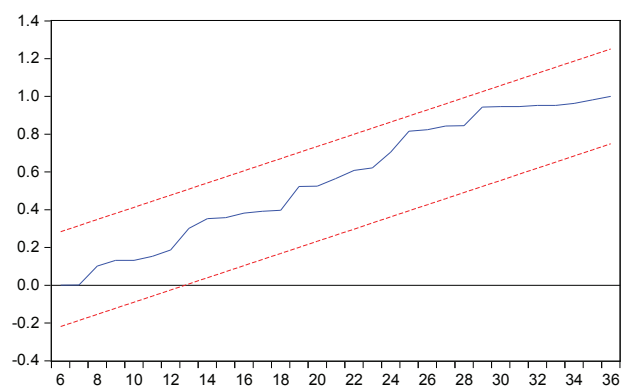

- CUSUM of Squares ----. $5 \%$ Significance

Figure 19. Women Wellbeing and Early Child Development (Coefficients Stability of Fifth Regression Equation through CUSUM Estimates)

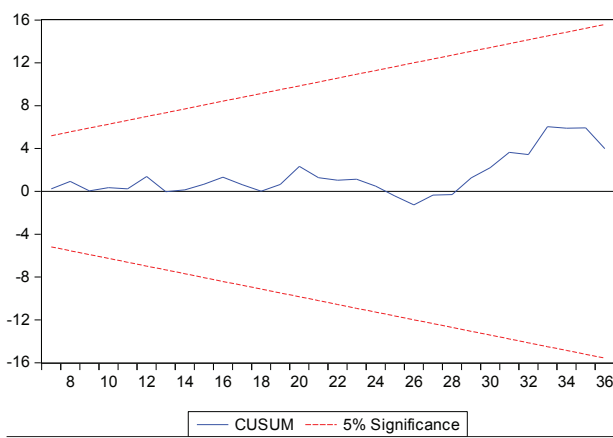

Figure 16. Women Wellbeing and Early Child Development (Coefficients Stability of Third Regression Equation through CUSUM of Squares Estimates)

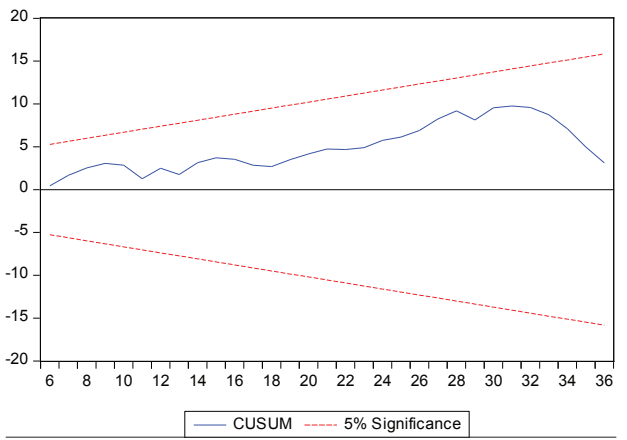

Figure 18. Women Wellbeing and Early Child Development (Coefficients Stability of Fourth Regression Equation through CUSUM of Squares Estimates)

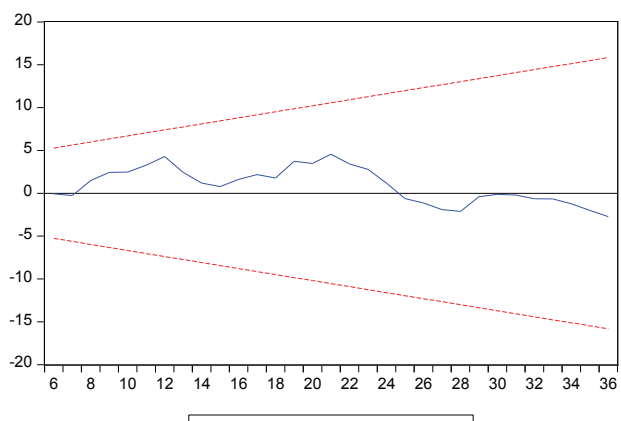
velopment (Coefficients Stability of Fifth Regression Equation through CUSUM of Squares Estimates) 


\section{Women Wellbeing and Fertility Results of all Diagnostic Tests}

\begin{tabular}{|l|c|c|c|c|c|c|c|c|c|c|}
\hline Diagnostic Test & F-St & Prob. & F-St & Prob. & F-St & Prob. & F-St & Prob. & F-St & Prob. \\
\hline $\begin{array}{l}\text { ARCH } \\
\text { Heteroskedasticity Test }\end{array}$ & 0.00 & 0.93 & 0.04 & 0.82 & 0.02 & 0.87 & 0.02 & 0.87 & 0.08 & 0.77 \\
\hline $\begin{array}{l}\text { B-Godfrey Serial } \\
\text { Correlation LM Test }\end{array}$ & 0.47 & 0.62 & 0.01 & 0.98 & 0.41 & 0.66 & 1.11 & 0.89 & 0.31 & 0.73 \\
\hline $\begin{array}{l}\text { Mean Variance Inflation } \\
\text { Factor }\end{array}$ & \multicolumn{2}{|c|}{1.61} & \multicolumn{2}{|c|}{1.35} & \multicolumn{2}{|c|}{2.12} & 2.21 & \multicolumn{2}{|c|}{1.71} \\
\hline
\end{tabular}

Source: Author's Calculation

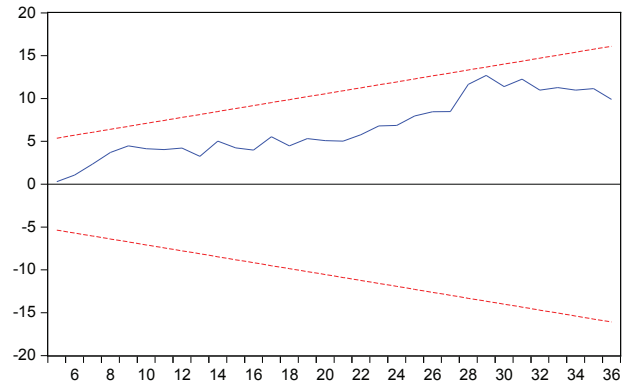

- CUSUM ---- $5 \%$ Significance

Figure 21. Women Wellbeing and Fertility (Coefficients Stability of First Regression Equation through CUSUM Estimates)

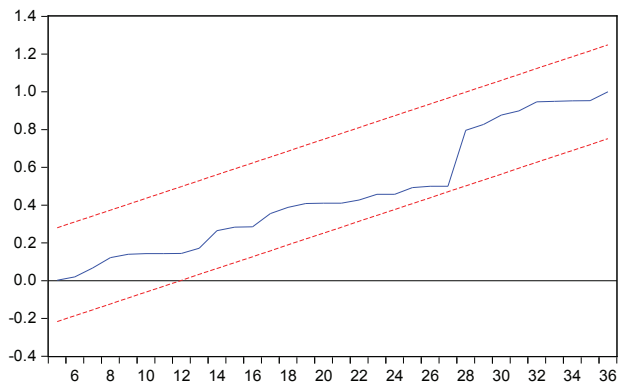

- CUSUM of Squares ---- $5 \%$ Significance

Figure 22. Women Wellbeing and Fertility (Coefficients Stability of First Regression Equation through CUSUM of Squares Estimates)

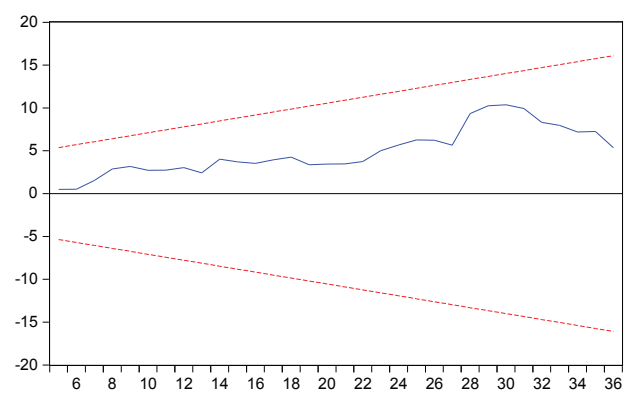

- CUSUM ---. $5 \%$ Significance

Figure 23. Women Wellbeing and Fertility (Coefficients Stability of Second Regression Equation through CUSUM Estimates)

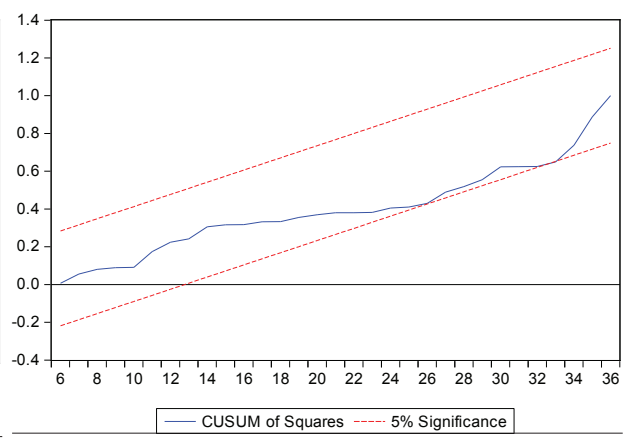

Figure 24. Women Wellbeing and Fertility (Coefficients Stability of Second Regression Equation through CUSUM of Squares Estimates) 


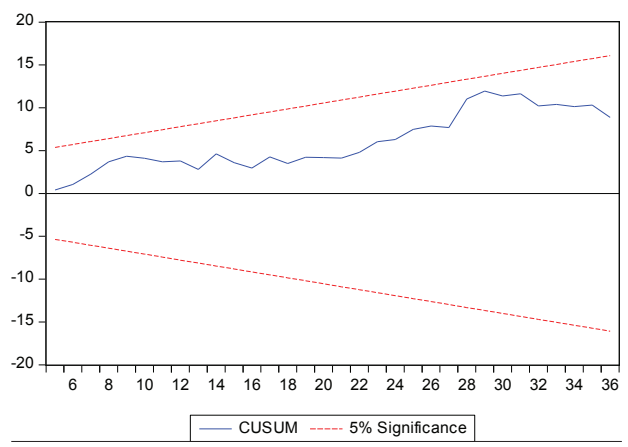

Figure 25. Women Wellbeing and Fertility (Coefficients Stability of Third Regression Equation through CUSUM Estimates)

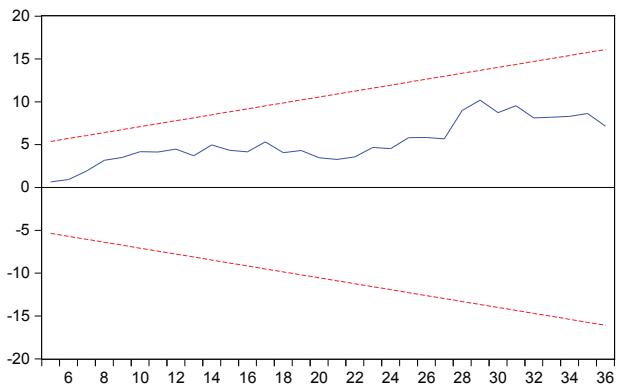

- CUSUM ----. $5 \%$ Significance

Figure 26. Women Wellbeing and Fertility (Coefficients Stability of Third Regression Equation through CUSUM of Squares Estimates)

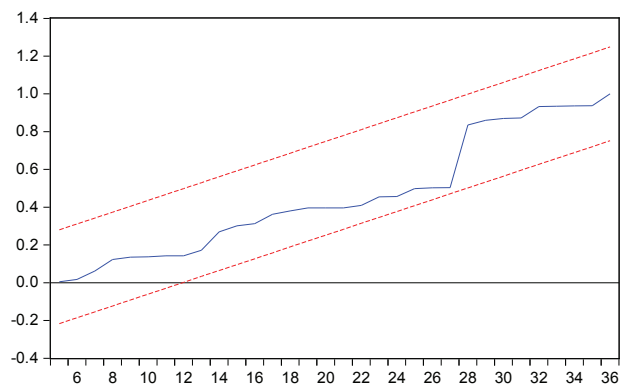

- CUSUM of Squares ----. $5 \%$ Significance

Figure 27. Women Wellbeing and Fertility (Coefficients Stability of Fourth Regression Equation through CUSUM Estimates)

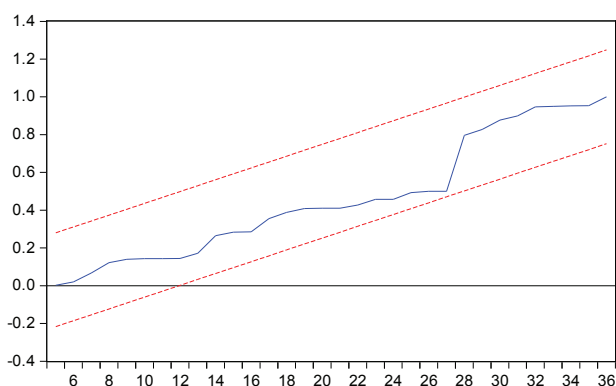

- CUSUM of Squares ----. $5 \%$ Significance

Figure 28. Women Wellbeing and Fertility (Coefficients Stability of Fourth Regression Equation through CUSUM of Squares Estimates)

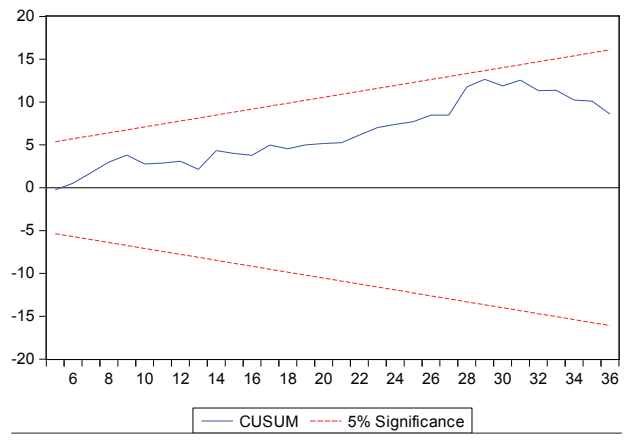

Figure 29. Women Wellbeing and Fertility (Coefficients Stability of Fifth Regression Equation through CUSUM Estimates)

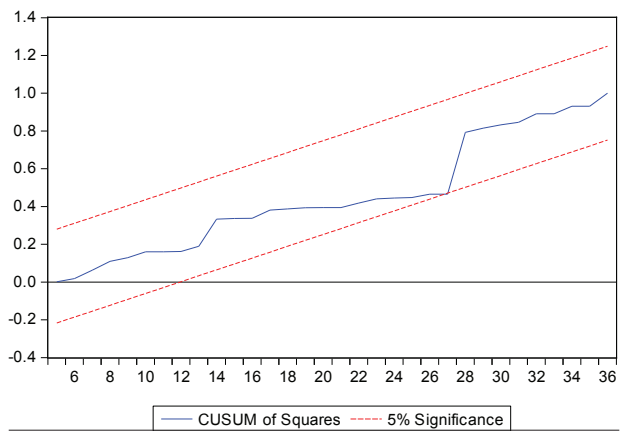

Figure 30. Women Wellbeing and Fertility (Coefficients Stability of Fifth Regression Equation through CUSUM of Squares Estimates) 


\section{Conclusion and Recommendation}

Present study has been estimated the impact of women wellbeing on demand and development of children across the districts of Punjab, Pakistan. Women wellbeing were quantified by constructing a composite index using four dimensions, economic well-being of women, social wellbeing of women, political awareness of women and satisfaction of women in various aspects of life. Principal Components Analysis (PCA) was applied to assigning weight in the construction of index. Total fertility rate was considered a proxy for demand of children. Early child development was measured by using early child development index with four domains, literacy-numeracy of children, learning of children, physical growth of children and socio-emotional development of children. By applying descriptive and regression analysis, this study found positive association of women wellbeing with early child development and its domains. While fertility was negatively correlated with women wellbeing and its dimensions. These empirical findings can be justified with existing literature related to the significance of women in the improvement of children and reduction of fertility. Promoting early child development is a targeted goal at national level as well as at global level. United Nations (UN) included early child development as sustainable goal and target for 2030 in all over the world. Almost, 250 million children, (43\%) proportion of under five-year age in developing economies are at risk of not attaining early child development properly (Black et al, 2016). This gap in human capital potential is partly because of many factors including lack of nurturing care of children. Nurturing care of children is directly linked with nutritional needs, protection from threats, opportunities of early learning and emotionally support from family especially from parents for health care, feeding care and behavioural care (Britto et al., 2017). Mothers' wellbeing has significant impacts on all mentioned components of children nurturing as concluded by Coyl et al. (2002), Farver et al. (2005), Newland et al. (2014), Rafferty, Griffin, \& Robokos (2010), Roggman, Boyce $\&$ Innocenti (2008). The ability of a mother to support the health and development of her children is critically dependent on her own health and wellbeing (Wang \& Eccles, 2012). Lower well-being of women is associated with low birth weight, stunting, childbirth complications, and less survival of children (Walker et al, 2015). Social, economic, emotional and political wellbeing of women is helpful to enhance child development as supported the current findings of this study. Learning, physical growth, nutritional improvement and emotional wellbeing of children are directly connected with women wellbeing. Women enhance their family income and improve child nutrition and health through labour force participation (Atkin, 2009) which dually effect to reduce poverty and on family standard of living (Augustine \& Papanyan, 2016). Female spend more as compared to men on family well-being (Hoddinott \& Haddad, 1995). Female have more saving behaviour and use credit more efficiently (Klasen \& Lammana, 2009; Goetz \& Gupta, 1996). The provision of credit or support through microcredit from NGO, s and financial institutes to 
female, it will enhance societal development (Ekesionye \& Okolo, 2012; Grasmuck \& Espinal, 2000; Schuler \& Hashemi, 1994). Female autonomy will decrease fertility rate and increase expenditure on child well-being (Abrar et al, 2017). Wellbeing of women increases opportunity cost of children, increase in cost of children reduces fertility which may increase saving per capita (Abrar et al, 2017). Empirical findings of this study support the theory of women wellbeing, demand and development of children, it affects positively to all dimensions of early child development. While fertility is affected negatively from all domains of women wellbeing.

In the light of empirical findings, improvement in all dimensions (economic wellbeing of women, social wellbeing of women, political awareness of women and satisfaction of women) of women wellbeing is suggested as useful strategy to enhance all domains (literacy-numeracy of children, learning of children, physical growth of children and socio-emotional development of children) of children and to reduce fertility. Developing economies have higher fertility and lower development of children as compared to developed economies. Lower child survival, malnutrition and lower immunization are clearly observable in developing countries. Lower wellbeing of women is one of the responsible factors of higher fertility and lower child development. Increasing education of women, provision of health facilities to women, creating job opportunities for women and increasing living standard of women is a significant and optimal strategy to reduce fertility and to enhance child development especially in developing economies.

\section{References}

Abrar ul Haq, M., Jali, M. R. B. M., \& Islam, G. M. N. (2016). Empowering rural women in Pakistan: empirical evidence from Southern Punjab. Quality and Quantity. Retrieved from http://link.springer.com/article/10.1007/s11135-016-0365-7

Aliyu, O. M., Schranz, M. E., \& Sharbel, T. F. (2010). Quantitative variation for apomictic reproduction in the genus Boechera (Brassicaceae). American Journal of Botany, 97(10), 1719-1731.

Ashraf, S., Abrar-ul-Haq, M., \& Ashraf, S. (2017). Domestic violence against Women: Empirical evidence from Pakistan. Pertanika Journal of Social Sciences and Humanities, 25(3), 1401-1418.

Atkin, D. (2009). Working for the future: Female factory work and child health in Mexico. Unpublished Manuscript, Yale University.

Augustine, A., \& Papanyan, S. (2016). ¿ Dónde están las mujeres?

Batliwala, S. (1994). The meaning of Womens empowerment: new concepts from action.

Becker, G. S., Murphy, K. M., \& Tamura, R. (2007). Human Capital, Fertility, and Economic Growth (No. 90-5a). Chicago-Population Research Center.

Belsky, J., \& Pluess, M. (2009). Beyond diathesis stress: Differential susceptibility to environmental influences. Psychological bulletin, 135(6), 885.

Benner, A. D., \& Kim, S. Y. (2010). Understanding Chinese American Adolescents' Developmental Outcomes: Insights From the Family Stress Model. Journal of Research on Adolescence, 20(1), 1-12. https://doi.org/10.1111/j.1532-7795.2009.00629.x 
Bick, A. (2016). The quantitative role of child care for female labor force participation and fertility. Journal of the European Economic Association, 14(3), 639-668.

Black, D. M., Delmas, P. D., Eastell, R., Reid, I. R., Boonen, S., Cauley, J. A., \& Mautalen, C. (2007). Once-yearly zoledronic acid for treatment of postmenopausal osteoporosis. New England Journal of Medicine, 356(18), 1809-1822.

Black, R. E., Levin, C., Walker, N., Chou, D., Liu, L., \& Temmerman, M. (2016). Reproductive, maternal, newborn, and child healthkey messages from Disease Control Priorities 3rd Edition. The Lancet, 388(10061), 2811-2824.

Blanc, A. K. (2001). The effect of power in sexual relationships on sexual and reproductive health: an examination of the evidence. Studies in family planning, 32(3), 189-213.

Blanchflower, D. G., \& Oswald, A. J. (2008). Is well-being U-shaped over the life cycle?. Social science \& medicine, 66(8), 1733-1749.

Bloom, D. E., \& Williamson, J. G. (1998). Demographic transitions and economic miracles in emerging Asia. The World Bank Economic Review, 12(3), 419-455.

Bohren, M. A., Vogel, J. P., Hunter, E. C., Lutsiv, O., Makh, S. K., Souza, J. P., ... Gülmezoglu, A. M. (2015). The Mistreatment of Women during Childbirth in Health Facilities Globally: A Mixed-Methods Systematic Review. PLOS Medicine, 12(6), e1001847. https://doi.org/10.1371/ journal.pmed.1001847

Brinda, E. M., Rajkumar, A. P., \& Enemark, U. (2015). Association between gender inequality index and child mortality rates: a cross-national study of 138 countries. BMC Public Health, 15(1), 97. https://doi.org/10.1186/s12889-015-1449-3

Britto, P. R., Lye, S. J., Proulx, K., Yousafzai, A. K., Matthews, S. G., Vaivada, T., ... \& MacMillan, H. (2017). Nurturing care: promoting early childhood development. The Lancet, 389(10064), 91-102.

Cabrera, N. J., Ryan, R. M., Mitchell, S. J., Shannon, J. D., \& Tamis-LeMonda, C. S. (2008). Low-income, nonresident father involvement with their toddlers: variation by fathers' race and ethnicity. Journal of Family Psychology, 22(4), 643.

Cain, M. (1984). Womens status and fertility in developing countries: son preference and economic security.

Case, A., \& Paxson, C. (2002). Parental behavior and child health. Health Affairs, 21(2), 164-178.

Chandra, P. S., Satyanarayana, V. A., Satishchandra, P., Satish, K. S., \& Kumar, M. (2009). Do men and women with HIV differ in their quality of life? A study from South India. AIDS and Behavior, 13(1), 110-117.

Chaudhary, A. R., Chani, M. I., \& Pervaiz, Z. (2012). An analysis of different approaches to women empowerment: a case study of Pakistan. World Appl Sci J, 16(7), 971-980.

Clark, R., Ramsbey, T. W., \& Adler, E. S. (1991). Culture, gender, and labor force participation: A cross-national study. Gender and Society, 47-66.

Coleman, D. (2004). Why we don't have to believe without doubting in the" Second Demographic Transition"- -some agnostic comments. Vienna yearbook of population research, 2, 11-24.

Conger, K. J., Rueter, M. A., \& Conger, R. D. (2000). The role of economic pressure in the lives of parents and their adolescents: the family stress model.

Conger, R. D., Ge, X., Elder, G. H., Lorenz, F. O., \& Simons, R. L. (1994). Economic stress, coercive family process, and developmental problems of adolescents. Child development, 65(2), 541-561. 
Coyl, D. D., Roggman, L. A., \& Newland, L. A. (2002). Stress, maternal depression, and negative mother-infant interactions in relation to infant attachment. Infant Mental Health Journal, 23(12), 145-163.

D'Acci, L. (2011). Measuring well-being and progress. Social Indicators Research, 104(1), 47-65.

Da Rocha, J. M., \& Fuster, L. (2006). Why are fertility rates and female employment ratios positively correlated across OECD countries?. International Economic Review, 47(4), 1187-1222.

Davidson, P. M., McGrath, S. J., Meleis, A. I., Stern, P., DiGiacomo, M., Dharmendra, T., \& Brown, H. (2011). The health of women and girls determines the health and well-being of our modern world: A white paper from the International Council on Women's Health Issues. Health care for women international, 32(10), 870-886.

De la Croix, D., \& Vander Donckt, M. (2010). Would empowering women initiate the demographic transition in least developed countries?. Journal of Human Capital, 4(2), 85-129.

Dipietro, L., Sabatini, A. M., \& Dario, P. (2008). A survey of glove-based systems and their applications. IEEE Transactions on Systems, Man, and Cybernetics, Part C (Applications and Reviews), 38(4), 461-482.

Doepke, M., \& Tertilt, M. (2014). Does female empowerment promote economic development? (No. w19888). National Bureau of Economic Research.

Duflo, E. (2012). Women Empowerment and Economic Development. Journal of Economic Literature, 50(4), 1051-1079. https://doi.org/10.1257/jel.50.4.1051

Dyson, T., \& Moore, M. (1983). On kinship structure, female autonomy, and demographic behavior in India. Population and development review, 35-60.

Ekesionye, E. N., \& Okolo, A. N. (2012). Women empowerment and participation in economic activities: Indispensable tools for self-reliance and development of Nigerian society. Educational Research and Reviews, 7(1), 10.

Falceto, O. G., Giugliani, E. R., \& Fernandes, C. L. C. (2004). Influence of parental mental health on early termination of breast-feeding: a case-control study. The Journal of the American Board of Family Practice, 17(3), 173-183.

Farver, J. A. M., Xu, Y., Eppe, S., Fernandez, A., \& Schwartz, D. (2005). Community violence, family conflict, and preschoolers' socioemotional functioning. Developmental psychology, 41(1), 160.

Fatima, A. \& H. Sultana (2009). "Tracing out the U-shape relationship between female labour force participation rate and economic development for Pakistan." International Journal of Social Economics Vol. 36, No.1/2, pp: 182-198.

Fatima, G. (2011). "Female Education as a determinant of Economic Growth: The case study of Pakistan." Contemporary Issues in Education Research Vol .4, No.11, pp.15.

Freeman, H., Newland, L. A., \& Coyl, D. D. (2008). Father beliefs as a mediator between contextual barriers and father involvement. Early Child Development and Care, 178(7-8), 803-819.

Freeman, H., Newland, L. A., \& Coyl, D. D. (2010). New directions in father attachment.

Fuchs, S. (2017). Female Employment and Higher Fertility - Policy Goals in Perfect Harmony? In Die transformative Macht der Demografie (pp. 127-137). Wiesbaden: Springer Fachmedien Wiesbaden. https://doi.org/10.1007/978-3-658-13166-1_9

Gage, A. J. (1995). Women's socioeconomic position and contraceptive behavior in Togo. Studies in Family Planning, 264-277.

Galler, J. R., Harrison, R. H., Ramsey, F., Chawla, S., \& Taylor, J. (2006). Postpartum feeding attitudes, maternal depression, and breastfeeding in Barbados. Infant Behavior and Development, 29(2), 189-203. 
Galler, J. R., Ramsey, F. C., Harrison, R. H., Taylor, J., Cumberbatch, G., \& Forde, V. (2004). Postpartum maternal moods and infant size predict performance on a national high school entrance examination. Journal of Child Psychology and Psychiatry, 45(6), 1064-1075.

Gennaro, S. (2005). Overview of current state of research on pregnancy outcomes in minority populations. American Journal of Obstetrics and Gynecology, 192(5), S3-S10.

Germain, A., \& Ordway, J. (1989). Population control and women s health: Balancing the scales.

Giallo, R., Wood, C. E., Jellett, R., \& Porter, R. (2013). Fatigue, wellbeing and parental self-efficacy in mothers of children with an autism spectrum disorder. Autism, 17(4), 465-480.

Glover, V. (2011). Annual research review: prenatal stress and the origins of psychopathology: an evolutionary perspective. Journal of Child Psychology and Psychiatry, 52(4), 356-367.

Goldin, C. (1986). Monitoring costs and occupational segregation by sex: a historical analysis. Journal of Labor Economics, 4(1), 1-27.

Goldin, C., (1986) "The female labor force and American Growth, 1890-1980." In Long term Factors in American economic growth (pp.557-604). University of Chicago Press.

Grote, N. K., Bridge, J. A., Gavin, A. R., Melville, J. L., Iyengar, S., \& Katon, W. J. (2010). A metaanalysis of depression during pregnancy and the risk of preterm birth, low birth weight, and intrauterine growth restriction. Archives of general psychiatry, 67(10), 1012-1024.

Hair, N. L., Hanson, J. L., Wolfe, B. L., \& Pollak, S. D. (2015). Association of child poverty, brain development, and academic achievement. JAMA Pediatrics, 169(9), 822-829.

Hindin, M. J. (2000). Women's autonomy, women's status and fertility-related behavior in Zimbabwe. Population Research and Policy Review, 19(3), 255-282.

Hirschman, C. (2001). Comment: Globalization and theories of fertility decline. Population and Development Review, 27, 116-125.

Hoddinott, J., \& Haddad, L. (1995). Does female income share influence household expenditures? Evidence from Côte d'Ivoire. Oxford Bulletin of Economics and Statistics, 57(1), 77-96.

Hoddinott, J., Alderman, H., Behrman, J. R., Haddad, L., \& Horton, S. (2013). The economic rationale for investing in stunting reduction. Maternal \& Child Nutrition, 9(S2), 69-82.

Hogg, R., Ritchie, D., Kok, B., Wood, C., \& Huby, G. (2013). Parenting support for families with young children-a public health, user-focused study undertaken in a semi-rural area of Scotland. Journal of clinical nursing, 22(7-8), 1140-1150.

Jacobson, J. L. (1992). Gender bias: roadblock to sustainable development.

Jejeebhoy, S. J. (1995). Women's education, autonomy, and reproductive behaviour: Experience from developing countries. OUP Catalogue.

Keegan, R., Spray, C., Harwood, C., \& Lavallee, D. (2010). The motivational atmosphere in youth sport: Coach, parent, and peer influences on motivation in specializing sport participants. Journal of applied sport psychology, 22(1), 87-105.

Khan, H. A., \& Raeside, R. (1997). Factors affecting the most recent fertility rates in urban-rural Bangladesh. Social Science \& Medicine, 44(3), 279-289.

Khan, M. M., Zafar, M. I., Ali, T., \& Ahmad, A. (2009). Effect of socio-economic, cultural and demographic factors on woman reproductive health. Pak. J. Agri. Sci, 46(4), 308-314.

Khayria, K.and R. Feki (2015) "Gender Inequality and Economic Development”. Business and Economics Journal Vol. 6, No. 4 pp. 1 
Klasen, S. (2000). Does gender inequality reduce growth and development? Evidence from crosscountry regressions.

Klasen, S., \& Lamanna, F. (2009). The impact of gender inequality in education and employment on economic growth: new evidence for a panel of countries. Feminist economics, 15(3), 91-132.

Kohler, H. P., Behrman, J. R., \& Skytthe, A. (2005). Partner+ Children= Happiness? The Effects of Partnerships and Fertility on Well-Being. Population and development review, 31(3), 407-445.

Kritz, M. M. (2000). The role of gender context in shaping reproductive behavior in Nigeria.

Kull, M. (2002). The relationships between physical activity, health status and psychological wellbeing of fertility-aged women. Scandinavian journal of medicine \& science in sports, 12(4), 241-247.

Lam, D., \& Duryea, S. (1999). Effects of schooling on fertility, labor supply, and investments in children, with evidence from Brazil. Journal of Human Resources, 160-192.

Lamb, M. E. (2010). How do fathers' influence children's development? Let me count the ways. The role of the father in child development, 1.

Lange, L., \& Randler, C. (2011). Morningness-eveningness and behavioural problems in adolescents. Sleep and Biological Rhythms, 9(1), 12-18.

LeVine, R. A., LeVine, S. E., Richman, A., Uribe, F. M. T., Correa, C. S., \& Miller, P. M. (1991). Women's schooling and child care in the demographic transition: A Mexican case study. The Population and Development Review, 459-496.

Lincove, J. A. (2008). "Growth, girls' education, and female labor: A longitudinal analysis." The Journal of Developing Areas 41(2): 45-68.

MacKenzie, M. J., Nicklas, E., Brooks-Gunn, J., \& Waldfogel, J. (2011). Who spanks infants and toddlers? Evidence from the fragile families and child well-being study. Children and youth services review, 33(8), 1364-1373.

Mason, K. O. (1987, September). The impact of women's social position on fertility in developing countries. In Sociological forum (Vol. 2, No. 4, pp. 718-745). Kluwer Academic Publishers.

Mason, K. O., \& Smith, H. L. (2000). Husbands'versus wives' fertility goals and use of contraception: The influence of gender context in five Asian countries. Demography, 37(3), 299-311.

McDonald, P. (2000). Gender equity in theories of fertility transition. Population and development review, 26(3), 427-439.

McKeown, K., Pratschke, J., \& Haase, T. (2003). Family Well-being: What makes a difference? Study based on a representative sample of parents and children in Ireland.

McLoyd, V. C. (1998). Socioeconomic disadvantage and child development. American psychologist, 53, 185.

Menon, U. (2013). Women, wellbeing, and the ethics of domesticity in an Odia Hindu temple town. Retrieved from https://link.springer.com/content/pdf/10.1007/978-81-322-0885-3.pdf

Minkovitz, C. S., Strobino, D., Scharfstein, D., Hou, W., Miller, T., Mistry, K. B., \& Swartz, K. (2005). Maternal depressive symptoms and children's receipt of health care in the first 3 years of life. Pediatrics, 115(2), 306-314.

Monte, L. M., \& Ellis, R. R. (2009). Fertility of women in the United States: 2012. Economics, 24, 1071-1100.

Moursund, A., \& Kravdal, O. (2003). Individual and community effects of women's education and autonomy on contraceptive use in India. Population studies, 57(3), 285-301. 
Mujahid, N. \& Zafar, N. (2012). "Economic growth-female labour force participation nexus: an empirical evidence for Pakistan." The Pakistan Development Review. Vol. 51, No.4, pp: 565-585.

Mukherjee, P \& Mukhopadhyay, I. (2013) "Impact of gender inequality on economic growth: A study of developing countries" IOSR Journal of Humanities and Social Science (IOSR-JHSS), Vol.13 No. 2 pp-61-69.

Newland, L. A. (2015). Family well-being, parenting, and child well-being: Pathways to healthy adjustment. Clinical Psychologist, 19(1), 3-14.

Newland, L. A., Coyl, D. D., \& Freeman, H. (2008). Predicting preschoolers' attachment security from fathers' involvement, internal working models, and use of social support. Early Child Development and Care, 178(7-8), 785-801.

Newland, R. P., Crnic, K. A., Cox, M. J., \& Mills-Koonce, W. R. (2013). The family model stress and maternal psychological symptoms: Mediated pathways from economic hardship to parenting. Journal of Family Psychology, 27(1), 96.

Ozerkek, Y. (2013). Unemployment and labor force participation: a panel co-integration analysis for European countries. Appl Econ Int Dev, 13(1), 67-76.

Pancer, S. M., Nelson, G., Hasford, J., \& Loomis, C. (2013). The Better Beginnings, Better Futures Project: Long-term Parent, Family, and Community Outcomes of a Universal, Comprehensive, Community-Based Prevention Approach for Primary School Children and their Families. Journal of Community \& Applied Social Psychology, 23(3), 187-205.

Patel, V., \& Prince, M. (2006). Maternal psychological morbidity and low birth weight in India. The British Journal of Psychiatry, 188(3), 284-285.

Peddie, V. L., Van Teijlingen, E., \& Bhattacharya, S. (2004). Ending in-vitro fertilization: women's perceptions of decision making. Human Fertility, 7(1), 31-37.

Petchesky, R. P. (1990). Feminist perspectives on reproductive rights since 1985. Petchesky and Weiner, 1-9.

Pluess, M., \& Belsky, J. (2013). Vantage sensitivity: Individual differences in response to positive experiences. Psychological bulletin, 139(4), 901.

Rafferty, Y., Griffin, K. W., \& Robokos, D. (2010). Maternal depression and parental distress among families in the Early Head Start Research and Evaluation Project: Risk factors within the family setting. Infant mental health journal, 31(5), 543-569.

Rees, R., \& Riezman, R. (2012). Globalization, gender, and growth. Review of Income and Wealth, 58(1), 107-117.

Rindfuss, R. R., Bumpass, L., \& St. John, C. (1980). Education and fertility: Implications for the roles women occupy. American Sociological Review, 431-447.

Rodenberg, B., \& Herrfahrdt-Pähle, E. (2012). The World Development Report 2012” Gender Equality and Development".

Roggman, L. A., Boyce, L., \& Innocenti, M. S. (2008). Developmental Parenting: A Guide for Early Childhood Practitioners.

Ruhm, C. J. (2004). Parental employment and child cognitive development. Journal of Human resources, 39(1), 155-192.

Salt, P., Galler, J. R., \& Ramsey, F. C. (1988). The Influence of Early Malnutrition on Subsequent Behavioral Development. VII. The Effects of Maternal Depressive Symptoms. Journal of Developmental \& Behavioral Pediatrics, 9(1), 1-5.

Sen, A. (1990). More than 100 million women are missing. The New York Review of Books, 37(20), 61-66. 
Sen, G., \& Batliwala, S. (2000). Empowering women for reproductive rights.

Sharma, A. (2008). Logics of empowerment: Development, gender, and governance in neoliberal India. U of Minnesota Press.

Sharma, S (2008): "Empowering Women through Education: Strategy for Sustainable Rural Development" Kurukshetra, A Journal on Rural Development, Vol.56, No.3.

Shieh, C.-J., Chou, J.-R., \& Ersozlu, Z. N. (2018). Performance evaluation of special education in China based on Data Envelopment Analysis. Quality \& Quantity. https://doi.org/10.1007/s11135-018-0706-9

Stillman, S., Gibson, J., McKenzie, D., \& Rohorua, H. (2015). Miserable migrants? Natural experiment evidence on international migration and objective and subjective well-being. World Development, 65, 79-93.

Surkan, P. J., Kennedy, C. E., Hurley, K. M., \& Black, M. M. (2011). Maternal depression and early childhood growth in developing countries: systematic review and meta-analysis. Bulletin of the World Health Organization, 89(8), 607-615.

Thomas, D. (1990). Intra-household resource allocation: An inferential approach. Journal of human resources, 635-664.

Topal, H., Ozkul, A. E., \& Dagli, G. (2017). Evaluation of health practices in the primary education in Cyprus in history. Quality \& Quantity. https://doi.org/10.1007/s11135-017-0672-7

Trommlerová, S. K., Klasen, S., \& Leßmann, O. (2015). Determinants of empowerment in a capability-based poverty approach: Evidence from the Gambia. World Development, 66, 1-15.

Trzcinski, E., \& Holst, E. (2012). Gender differences in subjective well-being in and out of management positions. Social indicators research, 107(3), 449-463.

Tsani, S., Paroussos, L., Fragiadakis, C., Charalambidis, I., \& Capros, P. (2013). Female labour force participation and economic growth in the South Mediterranean countries. Economics Letters, 120(2), 323-328.

Ulbrich, P., health, J. S.-W. \&, \& 2002, undefined. (2002). Making family planning clinics an empowerment zone for rural battered women. Taylor \& Francis, 35(2), 83-100. Retrieved from http://www.tandfonline.com/doi/abs/10.1300/J013v35n02_06

Ummanel, A., Şahin Kıralp, F. S., \& Yiğit, P. (2017). The first studies in family guidance in early childhood: the books of Dr. Hafiz Cemal. Quality \& Quantity. https://doi.org/10.1007/s11135-017-0639-8

Upadhyay, U. D., \& Karasek, D. (2012). Women's empowerment and ideal family size: an examination of DHS empowerment measures in Sub-Saharan Africa. International perspectives on sexual and reproductive health, 78-89.

Vandell, D. L., Belsky, J., Burchinal, M., Steinberg, L., \& Vandergrift, N. (2010). Do Effects of Early Child Care Extend to Age 15 Years? Results From the NICHD Study of Early Child Care and Youth Development. Child Development, 81(3), 737-756. https://doi.org/10.1111/j.14678624.2010.01431.x

Vogl, S. (2015). Children's verbal, interactive and cognitive skills and implications for interviews. Quality \& Quantity, 49(1), 319-338. https://doi.org/10.1007/s11135-013-9988-0

Vyas, S., \& Kumaranayake, L. (2006). Constructing socio-economic status indices: how to use principal components analysis. Health policy and planning, 21(6), 459-468.

Wadhwa, P. D., Sandman, C. A., Porto, M., Dunkel-Schetter, C., \& Garite, T. J. (2001). The association between prenatal stress and infant birth weight and gestational age at birth: a prospective investigation. American journal of obstetrics and gynecology, 169(4), 858-865. 
Walker, C. M., Gopnik, A., \& Ganea, P. A. (2015). Learning to learn from stories: Children's developing sensitivity to the causal structure of fictional worlds. Child development, 86(1), 310318.

Wanamaker, M. H. (2012). Industrialization and fertility in the nineteenth century: evidence from South Carolina. The Journal of Economic History, 72(1), 168-196.

Wang, M. T., \& Eccles, J. S. (2012). Social support matters: Longitudinal effects of social support on three dimensions of school engagement from middle to high school. Child development, 83(3), 877-895.

Weinstock, M. (2008). The long-term behavioural consequences of prenatal stress. Neuroscience \& Biobehavioral Reviews, 32(6), 1073-1086.

Woldemicael, G. (2009). Women's autonomy and reproductive preferences in Eritrea. Journal of Biosocial Science, 41(2), 161-181.

WHO (2005). World Health Organization: Addressing violence against women and achieving the Millennium Development Goals.

Xu, L. (2015). Effects of Female Political Participation on Economic Growth: Evidence from Asian Countries.

Ziegert, K. (2011). Maintaining families' well-being in everyday life. International Journal of Qualitative Studies on Health and Well-being, 6(2), 7206. 
